\title{
Shoot and Bud Development in Balsam Fir: Implications for Pruning of Christmas Trees
}

\begin{abstract}
The processes of development of shoots and buds of balsam fir (Abies balsamea (L.) Mill.) and the positions of buds of different types and with differing degrees of development, are described as a basis for understanding what happens in response to pruning of portions of shoots (shearing) at different times of year. The greatest response in shoot and bud development will result from pruning in late July and early August. Degree of response will decrease with advancing time of pruning from August to October. Pruning from late March to early May will produce less, bud significant response in subsequent bud development but little in first-season shoot development. Pruning from November to March can be as effective as pruning in late March and early April, but risks of damage are greater. Pruning in the most active phase of shoot elongation (June to mid-July) is not advisable.
\end{abstract}

\section{Résumé}

Pour comprendre ce qui se passe suite à l'élagage partiel des pousses à différentes périodes de l'année, on a fait la description des mécanismes de développement des pousses et des bourgeons du sapin baumier (Abies balsamea (L.) Mill.), en tenant compte de la position des bourgeons et du stade de développement. La meilleure réponse de développement de la pousse et du bourgeon survient suite à l'élagage de fin juillet et début août. Le niveau de réponse décroît ensuite d'août à octobre. L'élagage pratiqué tard en mars et jusqu'au début de mai donne une réaction moindre qui, tout en étant significative, reste faible en début de saison. L'élagage de novembre à mars peut être aussi efficace que l'élagage pratiqué tard en mars et au début d'avril, mais avec des risques plus élevés cependant. L'élagage n'est pas recommandé durant la phase la plus active de l'élongation des pousses (de juin au milieu de juillet).

\section{Introduction}

Pruning or shearing of branch tips and leaders, or shaping, of young balsam fir (Abies balsamea (L.) Mill.) grown for Christmas trees is a regular treatment (Bell and White 1966, McLeod 1968, Dickson and Winch 1978, Pinnock 1975). This treatment is designed to improve tree shape and to increase shoot density in the remaining crown. As a result, the grade of the tree is improved and the financial return to the grower is increased.

Advice in the literature on when to prune balsam fir is so varied that it must be confusing to the grower or field advisor. According to some authors (Bissell 1964, Bell and White 1966, Goodno et al. 1975) trees may be pruned at any time of year, although Bissell (1964) stated that most

${ }^{1}$ Department of Forest Resources, University of New Brunswick, Bag No. 44555 Fredericton, NB, E3B 6 C2 by

\author{
R. Powell ${ }^{1}$
}

growers prefer to prune in the fall, and Bell and White (1966) and Goodno et al.(1975) suggested that pruning in the dormant season (October to March), when other work pressures were less, was most practicable. Christie (1976) stated that trees should be pruned in the dormant season and Kidd et al. (1975) extended this to from early August to early April. Pinnock (1975) advised avoidance of pruning in late spring and early summer. Dickson and Winch (1978) gave late summer and fall as the best time to prune, early spring as the second choice, and winter as the third choice. Existence of a trend away from dormant season to growing season pruning was mentioned by McLeod (1968). He suggested that the best time to prune in the growing season was after the trees had completed most of their height growth, but while the new shoots were still soft.

The lack of consistency in advice on time of pruning results from inadequate understanding of the development processes which are influenced by pruning; indeed, the development processes are not mentioned in any of the cited items. The purpose of this paper is to use results of earlier research by the author (cited later) to describe the process and phenology of shoot elongation and bud development in balsam fir, and then to discuss the implications for pruning. This will provide understanding which can then be used with other practical factors (available workers, demands of other activities, etc.) for rational decisions concerning pruning of Christmas trees.

\section{Shoot Elongation and Bud Development}

Once balsam fir is past the seedling stage of development, its shoots elongate in two stages. The first stage is in late summer as elements of the shoot are formed within a bud. The second stage is in spring and early summer the next year as the preformed leaves and associated portions of stem are spread apart by their own expansion. This expansion occurs as a result of both cell division and cell enlargement, but not addition of new elements except some bud scales of the new terminal bud. The result of the first stage of elongation is a tiny ( $1 \mathrm{~mm}$ long) shoot primordium hidden within a bud, whereas that of the second is the fully extended shoot.

While recognizing that elongation of a single shoot occurs in portions of two consecutive growing seasons, it is convenient to divide each growing season into periods during which different growth activities occur in shoots and buds. Generally, the growing season is taken to occur from bud burst (usually late May or early June) to about the end of September. However, postdormancy shoot elongation starts in early April, at least 6 weeks before bud burst (Powell 1970a) and continues until mid-July. It is from then until late October that the shoot of the next year develops (Powell $1974,1977 \mathrm{a})$. The total growing season is therefore about $61 / 2$ months long. Three easily recognizable growth phases occur within it: the first phase is from the breaking of dormancy until bud burst, the second phase is from bud burst to the end of shoot elongation, and the third phase embraces bud maturation (Fig. 1). The precise timing of the phases will vary from place to place and from year to year: the dates given in what follows are averages for central New Brunswick. 


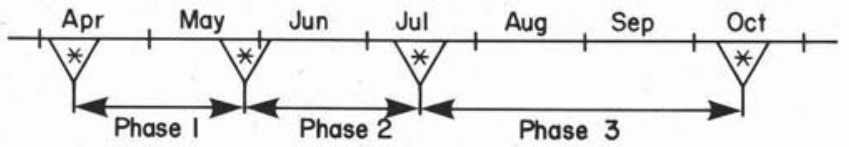

* Timing will vary with the climatic conditions of the year

Figure 1. Subdivision of the full growing season into three growth phases.

\section{Growth Phase 1}

In the first growth phase of the growing season, the preformed shoot within the overwintered bud starts to expand (Fig.2). Within the bud, the inner bud scales loosely overarch the shoot primordium and, at first, there is considerable space between the inner bud scales. The outer bud scales form a thick, resin-impregnated covering for the bud. The shoot primordium begins to expand as cells within it become active, enlarge and divide. The shoot first grows to fill the space inside the bud and presses the inner bud scales against the mass of outer bud scales. Continued expansion of the shoot causes the bud to swell. This becomes apparent by early to mid-May (Powell 1970a). The shoot bursts through its enclosing bud scales in late May to early June (Figs. 1 and 2): The rate of shoot expansion is largely controlled by accumulation of heat units (Sarvas 1965). The time of bud burst, and hence the end of Growth Phase 1, is therefore correlated with the weather conditions of the particular year.

The most significant event during shoot expansion within the overwintered bud is initiation of new buds. First, bud scales of the new terminal bud start to form on the flanks of the shoot apex about 3 weeks before the overwintered bud bursts (Powell 1977a). Then, a week before bud burst, lateral buds are initiated in axils of a few leaves along the elongating shoot (Powell 1974). Finally, at about the time of bud burst, subterminal buds are initiated in axils of some of the first-formed bud scales of the new terminal bud (Powell 1977a). The earliest stages of the new buds (bud primordia) can be seen only microscopically. Each lateral or subterminal bud primordium starts to form its own bud scales on its flanks. The first two bud scales (prophylls) always form on the sides of the buds which are parallel to the parent shoot axis, and then later bud scales are formed spirally around the new apex (Powell 1974, 1977a). By the time of bud burst, new terminal buds on vigorous shoots will have formed about 20 bud scales and lateral buds on the same shoots between three and six bud scales. Subterminal buds will only just have been initiated.

\section{Growth Phase 2}

Shoot elongation is rapid after bud burst (Fig. 5) until late June when it slows. It stops in mid-July, signifying the end of Growth Phase 2. Soon after bud burst, the newly forming buds can be seen if the leaves of the elongating shoot are parted. Lateral buds at that time are about 1 to $1.5 \mathrm{~mm}$ wide and appear as smooth yellowish mounds amongst the white pubescence of the shoot (Powell 1974). The terminal and subterminal buds form a yellowish clump at the shoot's summit.

Bud-scale production continues throughout Growth Phase 2 (Fig. 3), but production slows as the end of shoot elongation approaches (Fig. 5). The resulting buds, with full complements of bud scales, are able to go on to become mature buds in their first season. Although all initiated buds have the capacity to continue to produce bud scales throughout Growth Phase 2, many slow or cease bud-scale production early: they become latent (Powell 1974, 1977a). The cause of this is related to the general conditions for growth, the position of the buds on the shoots, the position of the shoots on the branch and in the crown, and local competition factors (Powell 1977b,c). Latent buds normally do not have the capacity for further development in their first growing season. However, it is the latent buds which can be forced into development in a subsequent season (Powell 1970b, 1974), and which therefore are of great significance in pruning.

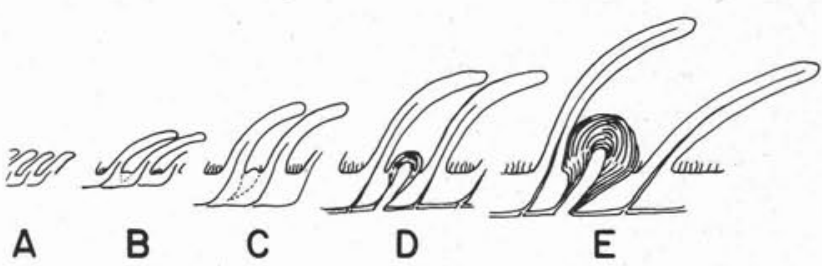

Figure 3. Lateral bud initiation and formation of bud scales: A. early in Growth Phase 1, shoot elongation starts; B. the first signs of initiation, a wedge of activity can be detected histochemically at a lateral bud position; C. late in Growth Phase 1, the lateral bud primordium is evident in the shoot surface; D. early in Growth Phase 2 , bud scales form around the new apex and the bud axis connects with the pith of the shoot; $E$. at the end of Growth Phase 2 the lateral bud which continues development to this time has a full complement of bud scales.

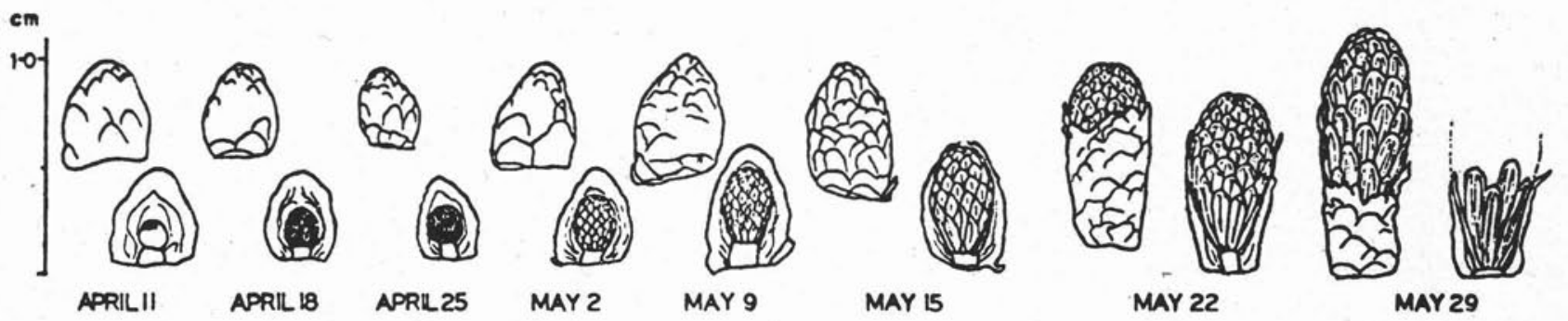

Figure 2. Internodal shoot development of balsam fir through Growth Phase 1 (April 11 to May 15) and into Growth Phase 2 as buds burst. The drawings are of separate lateral buds collected from one tree in 1968. For each date, the drawing on the left is of the complete bud or shoot, that on the right is of the same bud or shoot with the "front" bud scales cut away. 


\section{Growth Phase 3}

As shoot elongation ends and Growth Phase 3 begins, the new buds. which have acquired a full complement of bud scales and which have still-active apices, start to differentiate (Powell 1974). That is, they start to form a shoot primordium by initiating leaf primordia around the lower flanks of the shoot apices (Fig. 4). At the same time, the more recently formed bud scales increase in size and a wide receptacle develops at the base of the bud (Powell 1974, 1977a). This receptacle thickens and grows upwards around the outside of the shoot primordium and causes the older bud scales to spead outwards and the bases of the newer bud scales to be carried upwards. The whole bud thus increases in size and the lower part of the developing shoot primordium becomes protected by a thick outer coating of receptacle and bud scales, and its upper part by thin, overarching, paper-like inner bud scales, and then a thick layer of outer bud scales (Fig. 4). Large resin vesicles form in the receptacle and resin is exuded among the outer bud scales, and the whole bud becomes resin-coated. A protective layer also forms across the pith of the supporting axis below the shoot primordium. This nodal diaphragm, and its extension upwards on the inner walls of the receptacle, forms from late July to midAugust (Powell 1974). It consists of several layers of compact cells with thickened walls. The bud as a whole reaches its full size by mid-September. Inside, however, the shoot apex continues its production of leaf primordia. The rate of production of leaf primordia is high in late July and most of August, but then it slows but can continue into October. The shoot apex becomes dormant in October. By that time, the total leaf complement has been formed on the shoot primordium. This means that the number of leaves to be produced when that preformed shoot completes elongation in the next year is determined by the time the bud enters dormancy in late October.

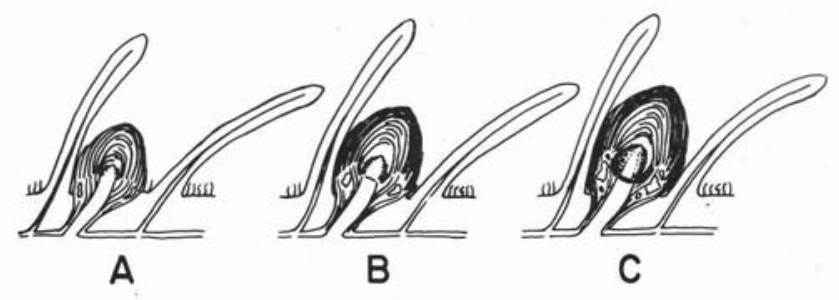

Figure 4. Shoot primordium formation in differentiated lateral buds: A. early in Growth Phase 3, leaf primordia begin to form on the lower flanks of the shoot apex as bud scales increase in size; B. the receptacle, at the base of the still-growing inner bud scales and outside of the pith and vascular traces, expands, resin vesicles within the receptacle become more apparent, and a nodal diaphragm begins to form across the pith below the developing shoot primordium; C. at the end of Growth Phase 3 , the lateral bud is complete, with a thick, resinimpregnated layer of outer bud scales, loosely packed inner bud scales, and the dormant, fully preformed shoot primordium protected across its base and around its lower sides by the nodal diaphragm and extensions of the diaphragm up the inside of the receptacle; the leaf (on the left), in the axil of which the bud was initiated, is forced into a more upright orientation by the growth of the bud.

\section{Summary of Activity in the Three Growth Phases}

The major events of the three growth phases are depicted in Fig. 5. In summary, balsam fir buds are initiated early in the season, before overwintered, fully formed buds burst. Bud-scale formation may continue until shoot elongation

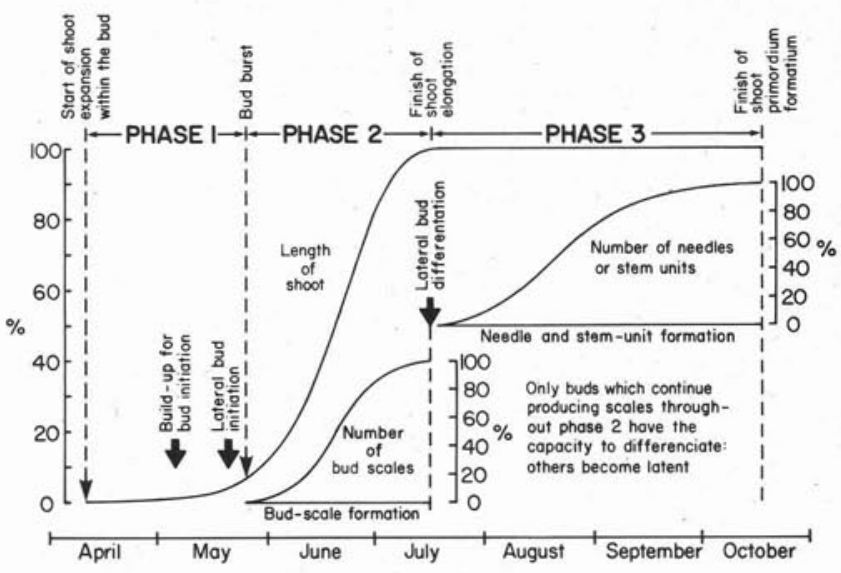

Figure 5. Patterns and phenology of shoot elongation, bud-scale formation, and needle formation on the shoot primordium for balsam fir during the three growth phases into which the growing season can be divided.

stops in mid-July: if it does, the buds are ready to differentiate new shoot primordia which will continue to develop until October; if it does not, the buds remain latent. Buds which complete development contain primordia for all the leaves which will develop on the shoot when it completes elongation in the next year.

It should also be recognized that other activities occur on the shoots as they grow. Once elongation has been completed at any given point along the shoot, secondary thickening (production of secondary xylem and secondary phloem by the cambium) begins, and the shoot becomes woody. Cambial activity in the new shoot probably continues only into the early part of Growth Phase 3; whereas, that in older shoots continues for longer (Loach and Little 1973).

\section{Numbers, Position, and Relative Development of Buds}

The number of buds initiated on a shoot is related to the length, and hence the vigor, of the shoot. The number of lateral buds produced increases linearly, and the number of buds in the terminal bud-unit (Powel 1977a) (terminal plus subterminals) increases curvilinearly with increasing shoot length (Fig. 6) (Powell 1970b). Between-tree variation in expression of these relationships is considerable, and so some trees inherently produce more buds per unit length of shoot than do others (Powell 1970b). This can be readily seen when one compares the numbers of nodal (or whorl) branches and internodal branches on different trees (Powell 1977b).

Lateral buds are not normally spaced evenly along a shoot of a branch. The proximalmost bud (nearest the base of the shoot) is usually positioned at about $30 \%$ of the distance along the shoot. If two lateral buds are borne, the second bud usually occurs at about $75 \%$ of the distance along the shoot (Powell 1977b). As more buds occur, they tend to be more concentrated towards the distal end of the shoot.

Lateral buds situated nearer the tips of the shoots tend to become fully formed buds more frequently, and to become larger buds, than do lateral buds situated in more proximal positions (Powell 1970b). So lateral buds with the largest preformed shoots are situated closest to the terminal budunit, and if latent buds occur, they are most likely to be positioned nearer the proximal end of the shoot. Among the buds of the terminal bud-unit, the terminal bud is characteristically larger than the subterminal buds. 


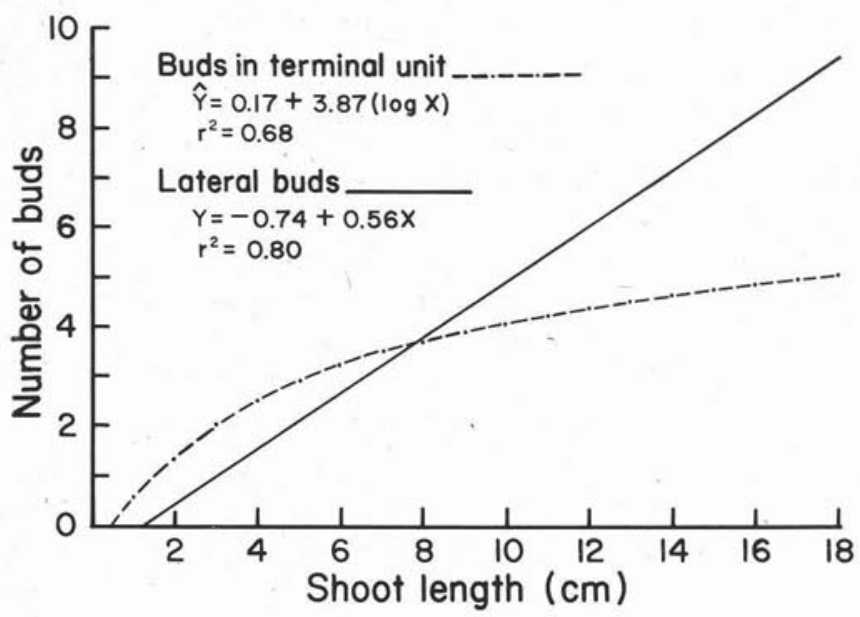

Figure 6. Relationships between numbers of buds in the terminal bud-unit, and numbers of lateral buds, and shoot length for all 214 shoots which elongated in one year in the upper three whorls of branches of one balsam fir tree.

When the fully formed buds burst the next year, the contained shoots elongate to lengths proportional to the relative numbers of leaf primordia they had produced (although the degree of expansion between the leaves may also be affected by the position along the parent shoot). It is therefore the pattern of distribution of different types, and of different amounts of preformed content, which results in the typical pattern of shoots of different lengths borne on one parent shoot (Fig. 7). Local competition for nutriment during the bud-development period is thought to be responsible for the different bud sizes (Powell 1977c). The terminal bud has the strongest drawing power for nutriment - it is the largest metabolic sink. Buds close to the terminal bud receive a spin-off effect, while those further away lose out, and thus have less opportunity to develop.

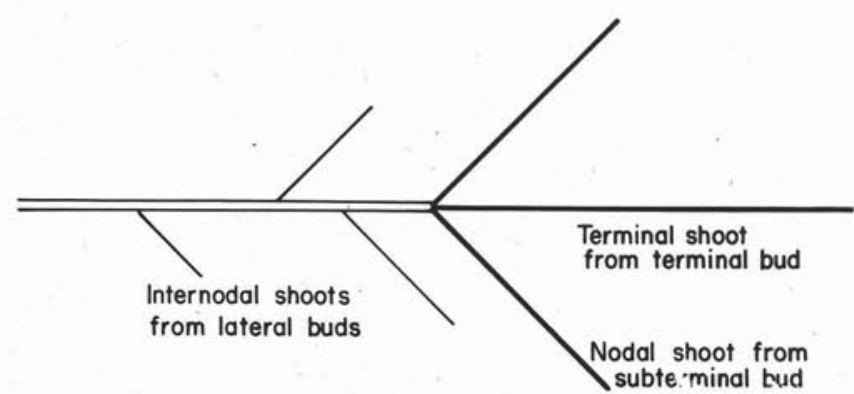

Figure 7. Typical pattern, for balsam fir, of shoot lengths in relation to position, and therefore type of shoot, along the parent shoot.

\section{Implications for Pruning}

Pruning cannot affect the process of bud development: it can affect the amount, placement, and reactivation of bud development. The possible response to pruning is influenced by the time of pruning, and the amount of shoot removed by pruning.

\section{Time of Pruning}

Pruning in the early part of Growth Phase 1 will remove more distally situated, and therefore stronger, overwintered buds in which activity was resuming. It will result in directing resources to overwintered buds further back on the shoot, thus enhancing their ability to develop. If such buds contain- ed preformed shoots, those shoots would likely elongate more, and initiate more buds than otherwise they would have done. If such buds were latent, then they (or at least the more distal of them) would be forced to develop into fully formed buds during the rest of the growing season, and therefore into elongated shoots in the subsequent growing season.

Pruning in the later part of Growth Phase 1 will be less effective because more resources will already have been used in shoot expansion within the overwintered buds, and in new bud initiation. Because buds would already have been initiated, additional initiation would be unlikely. Latent buds could respond and develop into fully formed buds, but delay in their growth promotion would result in less development. Pruning at this stage (May) might also result in considerable sap exudation (bleeding) which constitutes a loss of local resources.

Pruning in Growth Phase 2 would be ill advised because, with shoot elongation proceeding, it would be difficult to decide how much of the new shoot should be cut off. Also, it would have no effect on bud initiation in the current year, and response of latent buds would be limited. Buds already developing strongly and left near the ends of the cut shoots would, however, be favored with more resources, and so would grow proportionately larger. This would lead to greater shoot elongation and to better chances for more bud initiation on those shoots in the next growing season.

By Growth Phase 3, buds which are to develop shoot primordia will already have differentiated. Pruning of tissues distal to such buds will enhance the buds' development, and increase the number of leaf primordia formed within them. This, in turn, will increase the chances for more bud initiation the next year because there will be more positions in which buds could form. It will also result in greater shoot elongation the next year. The later in Growth Phase 3 that pruning is done, the less will be the effect. If only latent buds are left on the remaining shoot portions, they would not be affected until the next spring, but in that next spring they would experience maximum promotion. Pruning in Growth Phase 3 , especially early in the phase, will therefore elicit the greatest favorable response.

Pruning in the dormant season (November to March) will enhance the capability of remaining shoot primordia overwintering in buds to initiate lateral buds in the spring. Ensuing shoot elongation will also be greater than it would have been, but only because more resources will be available to the shoot: the number of leaves will not be increased. Pruning in the dormant season will also induce reactivation in latent buds so that they will develop and differentiate in the ensuing season. However, if shoots are cut in extremely cold conditions, the remaining shoot portions may be killed back and loss of remaining buds may result. Hence, if pruning is done in the dormant season, it should be limited to relatively warm periods.

\section{Amount of Shoot Removed by Pruning}

Pruning automatically removes the terminal and subterminal buds, which are the best developed buds. Depending on its severity, it may also remove most, or all of the differentiated lateral buds. In extreme cases, even all latent buds may be removed as well. Development of side shoots can only occur in the ensuing season if differentiated lateral buds remain.

If more than 70 percent of the length of a shoot is removed it is unlikely that any buds will be left on the shoot. Pruning of such severity cannot induce bud activity on that shoot. It would, possibly, induce activation of older latent buds on older shoots. Obviously, if the aim of the pruning is to force buds into development, initiated buds must be left on the remaining portions of the shoots. New buds will not normally form on old shoots. 


\section{Conclusions}

1. When biological processes are understood, the likely response to a particular treatment at any given time can be anticipated, and the merits of treatment at a particular time can be weighed against other management criteria.

2. Shoot elongation occurs in two stages, the first as elements of the shoot are laid down in the bud, the second as those preformed elements expand and the preformed leaves are spread apart. One can increase shoot elongation by inducing more shoot elements to form and (or) by providing better conditions for growth during the second and major stage of elongation. Pruning provides better local conditions for the portions of shoots remaining and hence for any buds they bear - and for any shoots developing from those buds.

3. Pruning in late July and early August will produce the greatest response in terms of shoot elongation from developing buds remaining on the pruned shoots and new bud formation in the next growing season. Effects would be of the same type but degree of response would decrease progressively from pruning in late August through September to early October.

4. Pruning in late March and early April will produce some increase in shoot elongation (but not from initiation of more leaves) and better development of buds initiated in the new season. This will lead to somewhat increased shoot growth in the subsequent growing season. Effects will be similar but lesser from pruning in late April and early May.

5. Pruning from late May to late July is not advised. Pruning in warmer periods from November to March can be as effective as that of late March and early April, but can result in shoot damage if cold weather follows.

\section{Acknowledgements}

I thank A. Dickson and J.E. MacDonald, Department of Forest Resources, University of New Brunswick, for their comments on the manuscript. The research on which this paper is based was supported by grants from the National Research Council of Canada, the New Brunswick Research and Productivity Council, and through the Canadian Forestry Service.

\section{References}

Bell, L.E. and D.P. White. 1966. Technical manual for Christmas tree farmers. Nitrogen Division, Allied Chemical Corporation, New York, NY, $126 \mathrm{p}$.

Bissell, L.P. 1964. Christmas tree harvest. Univ. Maine, Co-op. Extens. Serv., Bull 430, $19 \mathrm{p}$.

Christie, C. 1976. Managing wild balsam fir for Christmas trees. Nova Scotia Dept. Lands and For., $30 \mathrm{p}$.

Dickson, A. and F.E. Winch Jr. 1978. Shaping Christmas trees for quality. New York St. Coll. Agric. and Life Sci., Cornell Univ., Ithaca, NY, Extens. Publ., Inform. Bull. 81, 9 p.

Goodno, R.H., Giebel, and M. Silora. 1975. Massachusetts Christmas tree growers' handbook. Univ. Massachussetts, USDA, and County Extens. Serv., Co-op. Extens. Serv., Publ. $110,68 p$

Kidd, W.E. Jr., J.H. Brown, K.L. Carvell, F.C. Cech, and W.L. MacDonald. 1975. Chrismas tree culture and marketing. West Virginia Univ., Co-op. Extens. Serv., Publ. 525, 49 p.

Loach, K and C.H.A. Little. 1973. Production, storage, and use of photosynthate during shoot elongation in balsam fir (Abies balsamea). Can J. Bot. 51: 1161-1168.

McLeod J.W.1968. Christmas tree management in the Maritime Provinces, Part 1: Cultural practices. Can Dept. For. and Rural Devel., For. Res. Lab., Fredericton, NB, Inform. Rep. M-X-15, 30 p.

Pinnock, D.F. 1975. Establishment and care of balsam fir for Christmas trees. New Brunswick Dept. Agric. and Rural Devel., Plant Industry $\mathrm{Br}$., Fredericton, NB, $44 \mathrm{p}$.

Powell, G.R. 1970a. Postdormancy development and growth of microsporangiate and megasporangiate strobili of Abies balsamea. Can J. Bot. 48: 419-428.

Powell, G.R. 1970b. Some intrinsic factors affecting seed produc. tion in balsam fir. Ph.D. thesis, Univ. Edinburgh, Edinburgh, Scotland, $523 \mathrm{p}$.

Powell, G.R. 1974. Initiation and development of lateral buds in Abies balsamea. Can. J. For Res. 4: 458-469.

Powell, G.R. 1977a. Initiation and development of subterminal buds in Abies balsamea. Can. J. For Res. 7: 258-262

Powell, G.R. 1977b. Patterns of development in Abies balsamea crowns and effects of megastrobilus production on shoots and buds. Can. J. For. Res. 7: 498-509.

Powell, G.R. 1977c. Biennial strobilus production in balsam fir: a review of its morphogenesis and a discussion of its apparent physiological basis. Can. J. For. Res. 7: 547-555.

Sarvas, R. 1965. The annual period of development of forest trees. Proc. Finnish Acad. Sci. and Letters, 1965: 211-231.

\section{EDWARD

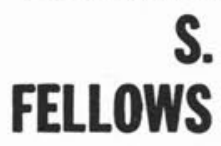

FORESTRY \& FOREST PRODUCTS CONSULTANT

P.O. Box 354, 404 Queen St., MEMBER:

FREDERICTON, N. B. Canadian Institute

Registered Professional of Forestry

Forest Products Research Society, Etc. kbm FORESTRY CONSULTANTS INC.

360 MOONEY STREET THUNDER BAY, ONTARIO

P7B 5R4

TEL.: $344-0811$

\author{
RESOURCE INVENTORY - \\ FOREST MANAGEMENT PLANNING \\ SILVICULTURAL SPECIALISTS \\ SYSTEM DESIGN AND CONTRACT
}

